\title{
Yesterdays Luxuries are Today's Necessities-A Review on Luxury cars.
}

\author{
Darshan $\mathrm{S}^{1}$, Dr.Y.T. Krishne Gowda ${ }^{2}$, \\ ${ }^{I}$ Research Scholar, Maharaja Research Foundation Mysore Karnataka, India \\ ${ }^{2}$ Professor Maharaja Institute of Technology Mysore Karnataka, India
}

\begin{abstract}
This review article made an attempt to throw light on the luxury cars which has become today's necessity and one of the important parameter in human life. The reviews made by the researchers before globalization and after globalization, have observed changes in this review paper.
\end{abstract}

Keywords: Globalization, Liberalization, Luxury cars, Brand consciousness, consumer behavior, customer perception, Disposable income

\section{Introduction}

Consumer buying behavior has become an integral part of strategic market planning. Indian Automobile car business is influenced by the presence of many national and multinational manufacturers. Factors are considered in existing study Social Parameters, Economical Parameters, Political Parameters, Product \& Technology Parameters, Demographic Parameters, Geographic Parameters, Psychographic Parameters and disposable income. The main attributes of luxury cars are durability, reliability and safety and the non-technical attributes are elegance, luxury brand image, prestige, and status. The automobile industry today is the most lucrative industry. Due to increase in disposable income in both rural and urban sector and availability of easy finance are the main drivers of high volume car segments. Further competition is heating up with host of new players coming in and global brands like Porsche, Bentley, and Ferrari all set to venture in Indian market. This paper will be helpful for the existing and new entrant car manufacturing companies in India to find out the customer expectations and their market offerings. Indian Automobile car business is influenced by the presence of many national and multinational manufacturers.

The liberalization policies followed by the Indian government had been inviting foreign players to participate in the car market in India. It is expected that by 2030, the Indian car market will be the third largest car market across the globe. The main encouraging factors for the success story of the car market in India are the increase in the opportunity for new investments, the rise in the GDP rate, the growing per capita income, massive population and high ownership capacity. Another independent study conducted by CLSA AsiaPacific Markets states that the count of millionaires in India are estimated to double and may cross the figures of 403,000 by 2015 . Which is a healthy indicator of increase in the demands of Luxury automakers such as Mercedes, BMW and Audi, who are shifting away from CBU operations to CKD assemblies to keep their products affordable. CKD operations are levied 10\% import duty, whereas completely assembled units are charged 75\% customs. Audi and Mercedes Benz will assemble their whole luxury SUV range in their local plants in 2013.

\section{Review:}

According to the research made by Rossiter and Prey (1987) brand awareness precedes all other steps in the buying process. A brand attitude cannot be performed, unless a consumer is aware of the brand. In memory theory, brand awareness is positioned as a vital first step in building the bundle of associations which are attached to the brand in memory. McKinsey (1990) Many experts have defined luxury in terms of price "luxury brands can be defined as those products whose price and quality ratios are the highest of the market" Solomon (1995)A consumer's buying behavior is influenced by cultural, social, personal and psychological factors. Most of these factors are uncontrollable and beyond the hands of marketers but they have to be considered while trying to understand the complex behavior of the consumers. Consumer is the study "of the processes involved when individuals or groups select, purchase, use, or dispose of products, services, ideas, or experiences to satisfy needs and desires". Fisher (2000) The production and consumption of cars in domestic markets and the Worldwide trade in cars is of economic as well as political significance. The car industry accounts for a significant portion of GDP in car producing countries affecting levels of employment and income, the balance of payments, economic growth and valuable inward foreign direct investment. For example, the UK is an important production site for American and Japanese car manufacturers. Phau and Prendergast (2000) The study described that luxury brands maintain their prestige by sustaining high levels of awareness and tightly controlled diffusion to enhance exclusivity to differentiate amongst luxury cars. Thus, Rolls-Royce, Bentley, 
Aston Martin, Ferrari and Lamborghini can be placed at the highest exclusivity and luxury and Mercedes, Jaguar, BMW and Audi placed at the "mass" luxury market based on price and availability. Old Luxury refers to the original exclusive products and brands which come from the houses which have long past histories, and who target only those individuals at a certain level of socioeconomic status. New luxury refers to, products and services that possess higher levels of quality, taste and aspiration than other goods in the category but are not so expensive as to be out of reach. New luxury brands use higher technology and have higher benefits and there are newer brands with the objective of showing higher involvement with consumers and gain customer loyalty.(Silverstein and Fiske 2005).

Velayutham and Brosekhan (2010) The study of consumer behavior is rapidly evolving as researchers recognize and implement new techniques and trans disciplinary perspectives to understand the nature of purchase and consumption behavior. This wider view attempts to study consumer behavior in the light of rapidly evolving lifestyles, values, priorities, and social contexts. Ramita Verma,Shubhkamana Rathore(2013) Researcher studied the luxury car segment of India. Researches and studies have revealed that the luxury car market is growing at a steady speed of $25 \%$ per annum with more and more numbers of luxury cars entering Indian car market. Luxury cars are preferred by HNI (High Net worth Individuals). HNI wants to differentiate themselves from crowd for various reasons. Change in attitude of the customer accounts for the sudden acceleration in the Luxury car Market in India, as the emphasis has been shifted from price consideration and affordability to design, quality and pleasure. Study also throws light on market drivers of luxury cars like political, economical and socio-cultural.

Schultz and Jain (2015)The term luxury is originated from the Latin word "luxus" (overabundance, indulgence, opulence, debauchery). Several attempts have been made to define luxury and notify consumers' attitude towards it (Schultz and Jain, 2015). The term luxury is originated from the Latin word "luxus" (overabundance, indulgence, opulence, debauchery). Several attempts have been made to define luxury and notify consumers' attitude towards it.Samit Chakraborty (2016) Through this research it has been observed that which single factor among interpersonal influence, brand image, brand consciousness is given maximum priority by Indian young consumers while making their selecting a brand or making a luxury brand purchase decision. From the result it has been explored that interpersonal influence has been given maximum priority or considered mostly by respondents compared to brand image and brand consciousness.

\section{Results and Discussion}

The existing and new entrant car manufacturing companies in India to find out the customer expectations and their market offerings.Customers have now changed their attitude that yesterday's luxuries are today's necessities. To be a successful marketer it is absolutely essential to study the perceptions of the prospective buyers and track their drivers of those perceptions. The change in the perception of prospective buyers and how the trend will look like in near future. In present scenario, the companies have completely changed their strategies and brand image as gone were the days when Indian buyers wanted to buy less expensive stuff moreover the people were not very brand conscious. But with the introduction of globalization and increase in the earning opportunity people have shown their strong inclination towards luxury cars whereas even till decade before the passenger cars were counted as luxury item. The scenario is completely opposite the cars are no more a luxury, a leap beyond in present the luxury cars are becoming necessity of every individual.

\section{Conclusion}

With the above review it has been clearly stated that the luxury car in India have become necessity of every individual, and also with the introduction of globalization the car manufacturers from different countries like Germany, Japan, Korea Etc. are en-cashing the opportunities to capture Indian market.

\section{Bibliography}

[1]. Rossiter JR\&PercyL (1987).Advertising and Promotion Management.Singapore: McGraw-Hill.

[2]. McKinsey, (1990), "The Luxury Industry: An Asset for France" Paris: McKinsey.

[3]. Solomon, M.R. (1995), Consumer Behaviour, 3rd Ed., Prentice Hall

[4]. Fisher,E.(2000)'Feminist Thought Implications for Consumer Research', Journal of Consumer Research,19.

[5]. Phau,I.\&Prendergast,G.(2000) Consuming luxury brands The relevance of the 'Rarity Principie',Brand Management,8 ,(2) .

[6]. Silverstein, M. and Fiske, N. (2005), Trading Up: The New American Luxury, New York: Penguin Group.

[7]. Abdul Brosekhan and Dr. C. Muthu Velayutham,(2010). Consumer Behaviour: Insights from Indian Market.PHI Learning Pvt. Ltd. to Masses. Palgrave Macmillan.

[8]. Ramita Verma, Shubhkamana Rathore (2013), PEST Analysis for Indian Luxurious Car Market, IJMSSR Vol. 2, No.1.

[9]. D.Schultz and V.Jain (2015) Discovering India's three levels of luxury consumption: An exploratory research to find a conceptual framework, Journal of Marketing Communications, 6(1).

[10]. Samit Chakraborty (2016), Department of International Fashion Retailing (BPI), School of Materials, The University of Manchester, Manchester, UK Accepted 14 April2016, Vol.6, No.2. 